\title{
Fatty acid composition and influence of temperature on the lipid stability of Arapaima gigas meat
}

\section{Composição de ácidos graxos e influência da temperatura na estabilidade lipídica de carne de Arapaima gigas}

\author{
Nathália Miranda Coutinho1, Anna Carolina Vilhena da Cruz Silva Canto1, \\ Eliane Teixeira Mársico', Flávio Alves da Silva², Luiz Antônio Moura Keller², \\ Carlos Adam Conte-Junior ${ }^{1}$, Maria Lúcia Guerra Monteiro ${ }^{1 *}$ (i)
}

${ }^{1}$ Universidade Federal Fluminense (UFF), Departamento de Tecnologia de Alimentos, Niterói/RJ - Brasil ${ }^{2}$ Universidade Federal de Goiás (UFG), Departamento de Engenharia de Alimentos, Niterói/RJ - Brasil

${ }^{3}$ Universidade Federal Fluminense (UFF), Departamento de Zootecnia e Desenvolvimento Agrossocioambiental Sustentável, Niterói/RJ - Brasil

\begin{abstract}
*Corresponding Author: Maria Lúcia Guerra Monteiro, Universidade Federal Fluminense (UFF), Departamento de Tecnologia de Alimentos, Rua Vital Brazil Filho, 64, Santa Rosa, CEP: 24230-340, Niterói/RJ, Brasil, e-mail: mariaguerra@id.uff.br
\end{abstract}

Cite as: Coutinho, N. M., Canto, A. C. V. C. S., Mársico, E. T., Silva, F. A., Keller, L. A. M., Conte-Junior, C. A. \& Monteiro, M. L. G. (2019). Fatty acid composition and influence of temperature on the lipid stability of Arapaima gigas meat. Brazilian Journal of Food Technology, 22, e2018132. https://doi.org/10.1590/1981-6723.13218.

\begin{abstract}
The nutritional quality and lipid stability of Arapaima gigas fillets were investigated. A total of $27.32 \mathrm{~kg}$ of $A$. gigas fillets were obtained and the proximate composition and fatty acid profile immediately determined. In addition, the lipid oxidation parameters were analyzed during 15 and 90 days at $4{ }^{\circ} \mathrm{C}$ and $-20^{\circ} \mathrm{C}$, respectively. The $A$. gigas fillets presented high protein $(>15 \%)$ and low lipid $(<2 \%)$ contents with elevated polyunsaturated fatty acid (PUFAs) contents (43.97\%). The nutritional quality indices were the atherogenicity index (0.35), thrombogenicity index (0.28) and the hypocholesterolemic acid/ hypercholesterolemic acid ratio (2.37). Overall, an increase followed by a decrease was observed in the peroxide index (PI) and malondialdehyde content (MDA) results at both storage temperatures $(p<0.05)$. The lipid profile exhibited great nutritional quality, however new conservation methods should be investigated for this matrix due to increased lipid oxidation during refrigerated and frozen storage.
\end{abstract}

Keywords: Pirarucu; Freshwater fish; Proximate composition; Lipid quality indices; Lipid oxidation; Gas chromatography.

\section{Resumo}

O objetivo deste estudo foi investigar a qualidade nutricional bem como a estabilidade lipídica de filés de Arapaima gigas. Um total de $27,32 \mathrm{~kg}$ de filés de $A$. gigas foi obtido e a composição centesimal e o perfil de ácidos graxos foram imediatamente determinados. Além disso, os parâmetros de oxidação lipídica foram analisados durante $15 \mathrm{e}$ 90 dias, a $4{ }^{\circ} \mathrm{C} \mathrm{e}-20{ }^{\circ} \mathrm{C}$, respectivamente. Os filés de $A$. gigas apresentaram elevado teor de proteína (>15\%) e baixa quantidade de lipídeos (<2\%), com elevado conteúdo de ácidos graxos poli-insaturados (AGPI) (43,97\%). Os índices de qualidade nutricional foram: índice de aterogenicidade $(0,35)$; índice de trombogenicidade $(0,28)$ e razão de ácidos graxos hipocolesterolêmico/hipercolesterolêmico (2,37). Em geral, um aumento seguido por uma diminuição 
foi observado nos resultados de índice de peróxidos (IP) e malonaldeído (MDA), em ambas as temperaturas de estocagem $(p<0,05)$. O perfil lipídico apresentou uma elevada qualidade nutricional, entretanto novos métodos de conservação devem ser investigados nesta matriz, devido ao aumento de oxidação lipídica durante a refrigeração e o congelamento.

Palavras-chave: Pirarucu; Peixe de água doce; Composição centesimal; Índices de qualidade lipídica; Oxidação lipídica; Cromatografia gasosa.

\section{Introduction}

Fish is considered to be a cheap source of nutrients with high biological quality, mainly due to the long-chain polyunsaturated fatty acid (PUFAs) contents (Buzzi et al., 1997), representing a great nutritional alternative compared to other types of meat matrix (Martínez-González et al., 2002). Freshwater fish are considered as important healthy products associated with a decrease in risk factors such as cardiovascular diseases, blood pressure, type 2 diabetes and chronic obstructive pulmonary disease (Simopoulos, 2009).

In general, the PUFA composition can vary depending on different factors such as diet, age, gender, environmental conditions and method of capture or fish removal (Huynh \& Kitts 2009). Freshwater fish contain less eicosapentaenoic acid (EPA, C20:5n-3) and docosahexaenoic acid (DHA, C22:6n-3) than marine fish. Moreover, in general freshwater fish show large amounts of the $n$-6 PUFAs, mainly linoleic acid (LA, C18:2n-6) and arachidonic acid (AA, C20:4n-6) (Hunter \& Roberts, 2000). LA serves as a barrier against water permeability in the skin, and is the origin of AA, which is the main precursor of the eicosanoid substances (prostaglandin, thromboxanes, leucotrienes) which act on the regulation of several physiological processes such as vasoconstriction, platelet aggregation and inflammation (Sanders, 2016; Simopoulos, 2009).

Nonetheless, the high concentration of PUFAs in this type of meat matrix leads to high lipid oxidation susceptibility due to double bond instability (Shichiri et al., 2014), resulting in degradation of the PUFAs, particularly of EPA and DHA (Gómez-Estaca et al., 2014), and the formation of detrimental compounds such as malondialdehyde (MDA) which increases the cardiovascular risk factors (Zaki et al., 2014).

Arapaima gigas is a native fish species from Brazil and presents potential farming characteristics, representing an economically viable alternative for aquaculture (Carani et al., 2008) mainly due to its weight gain and carcass yield (Fogaça et al., 2011).

Previous studies already investigated the production parameters (Fogaça et al., 2011; Imbiriba, 2001), proximate composition (Fogaça et al., 2011; Martins et al., 2015; Oliveira et al., 2014) and protein deterioration compounds during storage (Oliveira et al., 2014). However, very little research has focused on the nutritional quality of this specie, especially on the lipid portion, concerning which, to the best of the authors' knowledge, no study has been carried out up to the present moment. Therefore, the aim of the present study was to determine the proximate composition, characterize the lipid profile and investigate variations in the lipids during the refrigerated $\left(4^{\circ} \mathrm{C}\right)$ and frozen $\left(-20^{\circ} \mathrm{C}\right)$ storage of Arapaima gigas fillets.

\section{Material and methods}

\subsection{Experimental design}

Three specimens of Arapaima gigas were obtained from a fish farm located in a rural area of the state of

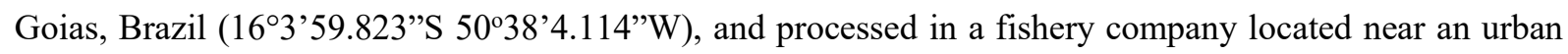
area of the same state $\left(16^{\circ} 36^{\prime} 52.890^{\prime \prime} \mathrm{S} 48^{\circ} 59^{\prime} 56.239^{\prime \prime} \mathrm{W}\right)$. The fishes were fasted for 2 days according to commercial practice, slaughtered in an ice bath, headed, eviscerated and filleted in the processing area. 
A total of $27.32 \mathrm{~kg}$ of $A$. gigas fillets were obtained with mean weight and length of $4.6 \pm 0.6 \mathrm{~kg}$ and $85.9 \pm 8.3 \mathrm{~cm}$, respectively. The fish samples were then packed, frozen $\left(-20^{\circ} \mathrm{C}\right)$ and transported in an ice box $\left(0{ }^{\circ} \mathrm{C}\right)$ to the laboratory, where they were randomly divided for storage at two different temperatures. One group was thawed at $4{ }^{\circ} \mathrm{C}$ overnight and the proximate composition and fatty acid profile immediately evaluated. In addition, lipid oxidation was examined in fish samples at six specific time points during refrigerated storage $\left(4^{\circ} \mathrm{C}\right)$ for 15 days. The other group was maintained frozen $\left(-20^{\circ} \mathrm{C}\right)$ and lipid oxidation evaluated at seven specific time points during 90 days of frozen storage. The present experiment was repeated three times $(n=3)$, totaling 87 experimental units.

\subsection{Proximate analysis}

The moisture, protein and ash contents were determined according to Association of Official Agricultural Chemists (2012). For the moisture determination, the samples were dried at $105^{\circ} \mathrm{C}$ to constant weight, the protein content was estimated using the Kjeldahl method $(\mathrm{N} \times 6.25)$ and the ash content was evaluated by incineration in a muffle furnace $\left(550^{\circ} \mathrm{C}\right)$. Moreover, the total lipid content was cold-extracted as described by Bligh \& Dyer (1959), extracting the total lipids from the fish samples $(5 \mathrm{~g})$ using a chloroform/methanol $(1: 2 \mathrm{v} / \mathrm{v})$ mixture. The carbohydrate content was calculated using the following equation $\%$ carbohydrate $=100 \%-(\%$ moisture $+\%$ protein $+\%$ ash $+\%$ lipid $)$, and the energy value was determined by multiplying the percentage of protein, lipid and carbohydrate contents by the respective energy values of 4, 9 and $4 \mathrm{kcal}$ (Merrill \& Watt, 1973). All analyses were carried out in triplicate.

\subsection{Lipid oxidation}

In order to better understand lipid oxidation during refrigerated storage $\left(4{ }^{\circ} \mathrm{C}\right)$, the fish samples were evaluated every other day up to the $15^{\text {th }}$ day. To evaluate lipid storage during frozen storage $\left(-20{ }^{\circ} \mathrm{C}\right)$, samples were taken every other week up to the $90^{\text {th }}$ day. The primary lipid oxidation products were determined according to the peroxide index (PI) by a colorimetric method using potassium iodide oxidation (Association of Official Agricultural Chemists, 2012) with a slight modification (3:1 acetic acid:chloroform solution, $\mathrm{v} / \mathrm{v}$ ). The results were expressed in milliequivalents of peroxide per kilogram of fish meat. The secondary lipid oxidation products were analyzed according to the thiobarbituric acid reactive substance (TBARS) method according to Tarladgis et al. (1960), as modified by Monteiro et al. (2012). The malondialdehyde (MDA) contents were calculated and the results expressed as mg MDA $/ \mathrm{kg}$ fish sample. All analyses were carried out in duplicate.

\subsection{Fatty acid profile}

The total lipids in the fish samples were cold-extracted according to Bligh \& Dyer (1959). Briefly, $5 \mathrm{~g}$ of fish sample were extracted using a mixture of methanol: chloroform $(2: 1 \mathrm{v} / \mathrm{v})$. The fatty acids were acid methylated (Chin et al., 1992; Conte-Junior et al., 2007; Kishino et al., 2002) and the fatty acid methyl esters (FAME) analyzed using gas chromatography coupled to a flame ionization detector (Perkin Elmer, Waltham, MA, USA). An Omegawax-320 column (polyethylene glycol, $30 \mathrm{~m}$ long, $0.32 \mathrm{~mm}$ internal diameter and $0.25 \mathrm{~mm}$ in film thickness) (Sulpeco, USA) and helium as the carrier gas (10 psi) were used yo separate the FAMEs. The injector (split of 1:20) and detector were maintained at $260{ }^{\circ} \mathrm{C}$ and $280{ }^{\circ} \mathrm{C}$, respectively. The initial column temperature was set at $110{ }^{\circ} \mathrm{C}$, increased at a rate of $40{ }^{\circ} \mathrm{C} /$ minute to $233{ }^{\circ} \mathrm{C}$, and held at this temperature for $2 \mathrm{~min}$. The temperature was then raised to $240{ }^{\circ} \mathrm{C}$ at $1{ }^{\circ} \mathrm{C} /$ minute and held at this temperature for $21 \mathrm{~min}$. The FAMEs present in the fish samples were identified by a comparison of their retention times with a commercial standard containing 37 fatty acid methyl esters (Sigma-Aldrich, St. Louis, MO, USA). All analyses were carried out in triplicate. 


\subsection{Lipid nutritional quality indices (NQIs)}

The nutritional quality of the A. gigas fillets was determined according to three nutritional indices: the atherogenicity index (AI) and thrombogenicity index (TI) according to Ulbricht and Southgate (1991) with slight modifications as described by Canto et al. (2015), and the hypocholesterolemic to hypercholesterolemic ratio $(\mathrm{H} / \mathrm{H})$ according to Santos-Silva et al. (2002), using the following calculations (1):

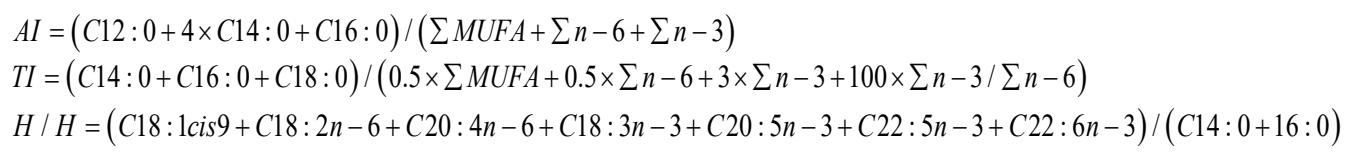

\subsection{Statistical analyses}

One-way ANOVA was carried out to evaluate the proximate composition, fatty acid profile and lipid oxidation (during the storage time) in the Arapaima gigas samples, using the XLSTAT version 2012.6.08 (Addinsoft, Paris, France). Significant differences between the mean values were determined using Tukey's test at a $95 \%$ confidence level $(p<0.05)$.

\section{Results and discussion}

\subsection{Proximate composition}

The proximate composition results are presented in Table 1. According to Haard (1992), fish are commonly classified into groups according to their total lipid content: lean $(<2 \%)$, low-fat $(2 \%$ to $4 \%)$, medium-fat ( $4 \%$ to $8 \%)$ and high-fat ( $>8 \%)$. In addition, $15 \%$ of protein content can be considered as a high level (Memon et al., 2011). Thus, the present findings indicate that the A. gigas fillets can be considered as lean meat with a high protein content, resulting in a low energy value $(99.44 \mathrm{kcal} / 100 \mathrm{~g})$, results similar to those of previous studies with A. gigas fillets (Fogaça et al., 2011; Oliveira et al., 2014).

Table 1. Proximate composition of Arapaima gigas fillets.

\begin{tabular}{cc}
\hline Parameters (\%) & Mean \pm SD* \\
\hline Moisture & $75.84 \pm 0.82$ \\
Protein & $20.97 \pm 0.73$ \\
Ash & $1.15 \pm 0.03$ \\
Lipid & $1.48 \pm 0.18$ \\
Carbohydrates & $0.56 \pm 0.10$ \\
\hline
\end{tabular}

*Values are expressed as the mean \pm standard derivation $(n=3)$.

Regarding the proximate composition of the farmed A. gigas, similar total lipid (Oliveira et al., 2014), protein (Fogaça et al., 2011; Martins et al., 2015), moisture (Martins et al., 2015) and ash (Martins et al., 2015; Oliveira et al., 2014) contents were previously reported in the literature. Nonetheless, Martins et al. (2015) reported a higher total lipid content (2.60\%) whereas Oliveira et al. (2014) observed a lower protein content (16.83\%) in A. gigas meat. The variation in the proximate data observed as compared to aformentined studies can be explained by the high variability of fish composition depending on the species, season, environment, diet, age and sex (Martins et al., 2015). In general, the lipid and protein contents are the most variable components in farmed fish, which depend on the feeding and fish muscle activity (Thammapat et al., 2010). 


\subsection{Lipid oxidation at different storage temperatures}

To the best of the authors' knowledge, there are no data regarding the lipid stability of $A$. gigas meat during refrigerated $\left(4{ }^{\circ} \mathrm{C}\right)$ and frozen $\left(-20^{\circ} \mathrm{C}\right)$ storage. Lipid oxidation was evaluated by determining the PI and MDA during 15 days under refrigerated storage and 90 days under frozen storage (Tables 2 and 3, respectively). During refrigerated storage $\left(4^{\circ} \mathrm{C}\right)$ the PI increased on day $9(p<0.05)$ but decreased on day $15(p<0.05)$, whereas under frozen storage $\left(-20^{\circ} \mathrm{C}\right)$, the PI increased on day 30 and decreased on day $45(p<0.05)$. A similar pattern for PI was observed in Lates calcarifer during 12 days at $4{ }^{\circ} \mathrm{C}$ (Arfat et al., 2015) as well as in Atlantic halibut during 12 months of frozen storage (Abreu et al., 2011).

Table 2. Lipid oxidation in Arapaima gigas fillets stored at $4{ }^{\circ} \mathrm{C}$ for 15 days.

\begin{tabular}{ccc}
\hline Refrigerated storage time (days) & PI $(\mathbf{m E q} / \mathbf{k g})$ & MDA $(\mathbf{m g} / \mathbf{k g})$ \\
\hline 0 & $1.62 \pm 0.09^{\mathrm{b}}$ & $0.09 \pm 0.01^{\mathrm{ab}}$ \\
3 & $1.30 \pm 0.18^{\mathrm{b}}$ & $0.10 \pm 0.01^{\mathrm{a}}$ \\
6 & $1.67 \pm 0.09^{\mathrm{b}}$ & $0.07 \pm 0.00^{\mathrm{bc}}$ \\
9 & $2.30 \pm 0.08^{\mathrm{a}}$ & $0.05 \pm 0.01^{\mathrm{cd}}$ \\
12 & $2.55 \pm 0.17^{\mathrm{a}}$ & $0.04 \pm 0.01^{\mathrm{d}}$ \\
15 & $1.34 \pm 0.07^{\mathrm{b}}$ & $0.06 \pm 0.01^{\mathrm{cd}}$ \\
\hline Values are expressed as the mean \pm standard derivation $(\mathrm{n}=3)$. PI: peroxide index; mEq: milliequivalents; MDA: malondialdehyde.
\end{tabular}

Different letters in the same column represent significant difference $(p<0.05)$.

Table 3. Lipid oxidation in Arapaima gigas fillets stored at $-20{ }^{\circ} \mathrm{C}$ for 90 days.

\begin{tabular}{ccc}
\hline Frozen storage time (days) & PI ( $\mathbf{m E q} / \mathbf{k g})$ & MDA $(\mathbf{m g} / \mathbf{k g})$ \\
\hline 0 & $1.62 \pm 0.09^{\mathrm{b}}$ & $0.09 \pm 0.01^{\mathrm{ab}}$ \\
15 & $2.70 \pm 0.19^{\mathrm{b}}$ & $0.08 \pm 0.01^{\mathrm{b}}$ \\
30 & $4.55 \pm 0.40^{\mathrm{a}}$ & $0.08 \pm 0.02^{\mathrm{bc}}$ \\
45 & $2.32 \pm 0.09^{\mathrm{b}}$ & $0.11 \pm 0.01^{\mathrm{a}}$ \\
60 & $1.19 \pm 0.11^{\mathrm{b}}$ & $0.05 \pm 0.01^{\mathrm{c}}$ \\
75 & $1.45 \pm 0.01^{\mathrm{b}}$ & $0.07 \pm 0.03^{\mathrm{bc}}$ \\
90 & $1.06 \pm 0.15^{\mathrm{b}}$ & $0.09 \pm 0.01^{\mathrm{bc}}$ \\
\hline
\end{tabular}

Values are expressed as the mean \pm standard derivation $(\mathrm{n}=3)$. PI: peroxide index; mEq: milliequivalents; MDA: malondialdehyde. Different letters in the same column represent significant difference $(p<0.05)$.

Regarding the MDA values, in general the A. gigas fillets demonstrated a decrease $(p<0.05)$ on day 12 during refrigerated storage. According to Monteiro et al. (2012), Intarasirisawat et al. (2014) and Santos et al. (2018), a similar trend was observed for MDA formation in Nile tilapia, fish (Clarias macrocephalus) emulsion sausage and Arapaima gigas fillets stored under refrigeration. Regarding the frozen samples, the A. gigas fillets generally exhibited higher MDA values on day 45 than on days 15 and $30(p<0.05)$, but nevertheless a decrease was observed on day $60(p<0.05)$. A similar trend was observed by Abreu et al. (2011) for Atlantic halibut stored at $-20{ }^{\circ} \mathrm{C}$.

Peroxides are the primary products of lipid oxidation whereas aldehydes, ketones, alkanes and other products are secondary compounds of lipid oxidation (Guéraud et al., 2010; Guyon et al., 2016; Kumar et al., 2015). Thus a decrease in the peroxide level might be attributed to their degradation as a result of secondary oxidation reactions (López-de-Dicastillo et al., 2012). Moreover, the decrease observed in the MDA values can be attributed to a loss of secondary oxidation products due to their volatility, or to the ability of malondialdehyde to form covalent bonds with alkaline compounds from the degradation process (Intarasirisawat et al., 2014) in agreement with the results of the present study in which when the PI values were low, the MDA values were high.

In addition, an increase in the MDA values decreases the paraoxonase (PON1) level, leading to greater cardiovascular risk factors, such as atherosclerosis, coronary heart disease, hyperlipidemia, diabetes and hypertension (Zaki et al., 2014). Furthermore, increases in the PI and MDA values were also observed 
during frozen storage, potentially due to endogenous enzyme activities such as lipoxygenase, which, in turn, can be active at low temperatures and be considered a limiting factor for the storage period and fish commercialization (Abreu et al., 2011).

\subsection{Fatty acid profile}

A total of twenty one fatty acids were detected in the A. gigas fillets (Table 4), 26.7\% being saturated fatty acids (SFA), $29.19 \%$ monounsaturated fatty acids (MUFA) and $43.97 \%$ polyunsaturated fatty acids (PUFA). In general, freshwater fish present low SFA values $(<30 \%)$ (Ackman, 1989) indicating a high nutritional quality of the lipid fraction in agreement with the present findings.

Table 4. Fatty acid composition of the muscle tissue of the Arapaima gigas fillets, expressed as percentages of fatty acids (\%).

\begin{tabular}{|c|c|}
\hline Fatty Acids & Mean \pm SD* \\
\hline $\mathrm{C} 12: 0$ & $0.15 \pm 0.01$ \\
\hline C14:0 & $0.52 \pm 0.01$ \\
\hline $\mathrm{C} 16: 0$ & $22.32 \pm 1.74$ \\
\hline C18:0 & $0.74 \pm 0.26$ \\
\hline $\mathrm{C} 22: 0$ & $1.96 \pm 0.57$ \\
\hline ESFA & $26.7 \pm 1.85$ \\
\hline C16:1 & $1.25 \pm 0.09$ \\
\hline C18:1n-7 & $2.88 \pm 1.17$ \\
\hline C18:1n-9 & $17.82 \pm 0.48$ \\
\hline C20:1 & $0.34 \pm 0.01$ \\
\hline $\mathrm{C} 22: 1 n-9$ & $1.07 \pm 0.53$ \\
\hline C24:1 & $5.83 \pm 0.17$ \\
\hline EMUFA & $29.19 \pm 1.88$ \\
\hline $\mathrm{C} 18: 2 n-6$ & $25.74 \pm 2.53$ \\
\hline $\mathrm{C} 18: 3 n-6$ & $1.51 \pm 0.45$ \\
\hline $\mathrm{C} 18: 3 n-3$ & $0.31 \pm 0.19$ \\
\hline C20:2 & $0.59 \pm 0.39$ \\
\hline $\mathrm{C} 20: 3 n-6$ & $2.77 \pm 0.66$ \\
\hline $\mathrm{C} 20: 3 n-3$ & $0.32 \pm 0.14$ \\
\hline $\mathrm{C} 20: 4 n-6$ & $3.68 \pm 0.32$ \\
\hline C22:2 & $0.22 \pm 0.04$ \\
\hline $\mathrm{C} 20: 5 n-3$ & $0.23 \pm 0.05$ \\
\hline $\mathrm{C} 22: 6 n-3$ & $8.59 \pm 0.59$ \\
\hline इPUFA & $43.97 \pm 1.84$ \\
\hline$\Sigma n-3$ & $9.45 \pm 0.61$ \\
\hline$\Sigma n-6$ & $33.70 \pm 2.17$ \\
\hline
\end{tabular}

*Values expressed as the mean \pm standard derivation $(n=3)$. SFA: saturated fatty acid; MUFA: monounsaturated fatty acid; PUFA: polyunsaturated fatty acid.

Furthermore, a PUFA $>$ MUFA $>$ SFA pattern was observed in accordance with other freshwater fish studies in Mastacembelus simack (Harlioglu; Yilmaz, 2011), Labeo rohita, Cirrhinus mrigala, Catla catla (Memon et al., 2011) and Onchorynchus mykiss (Volpe et al., 2015).

Of the SFAs, the most abundant fatty acid was palmitic (C16:0), which is an important energy source during fish growth (Henderson et al., 1984). Of the MUFAs, the main fatty acid observed in A. gigas was oleic acid (C18:1n-9), a fatty acid related to the type of fish diet (Ackman, 1989). Similar findings were reported for Labeo rohita, Cirrhinus mrigala, Catla catla (Memon et al., 2011) and Salmo trutta macrostigma (Ateş et al., 2013) species, for which C16:0 and C18:1n-9 were the major fatty acids present representing the SFA and MUFA contents, respectively. In addition, erucic acid (22:1n-9) was determined in this fish specie. In agreement with the present findings, Jankowska et al. (2003) studied Sander 
lucioperca raised on a farm and taken from wild life, and only detected 22:1n-9 in the lipid fraction of the farmed species, suggesting that this MUFA came from the farmed fish feed.

Regarding the amount of PUFAs, the major fatty acids detected were C18:2n-6 (LA), C20:4n-6 (AA) and C22:6n-3 (DHA). In general, freshwater fishes contain more $n-6$ PUFAs (Çelik et al., 2005), reflecting in lower $n-3 / n-6$ PUFA ratios than in marine fishes (Hunter \& Roberts, 2000). The high C18:2n-6 level exhibited in A. gigas may be due to the presence of this fatty acid in plant oil, usually added to farmed fish feeds (Grigorakis et al., 2002). Furthermore, the aforementioned specie also demonstrated a great amount of AA $(20: 4 n-6)$, which is a precursor of metabolic eicosanoid products, specifically prostaglandin and thromboxane, and plays an important role in the brain as well as in the retina (Simopoulos, 2009). In agreement with the present results, Jabeen \& Chaudhry (2011) also reported high levels of $n-6$ PUFA, mainly linoleic (18:2) and arachidonic (22:4) acids in Cyprinus carpio, Labeo rohita, and Oreochromis mossambicus. Moreover, Volpe et al. (2015) also observed a dominant percentage of $n-6$ PUFA in Onchorynchus mykiss, a freshwater fish specie.

Regarding the $n-3$ family, A. gigas was shown to be a great source of DHA (22:6n-3) but had low contents of EPA (20:5n-3). These long-chain fatty acids are considered important in the prevention of coronary heart disease and inflammatory processes (Simopoulos, 2009). In agreement with the present results, Navarro et al. (2012) reported small amounts of EPA (20:5n-3) in Oreochromis niloticus. In addition, other researchers also demonstrated high DHA (22:6n-3) contents in freshwater fishes such as S. trutta macrostigma (Ateş et al., 2013) and Onchorynchus mykiss (Volpe et al., 2015).

Table 5 shows the PUFA/SFA, n- $6 / n-3$ and $n-3 / n-6$ ratios. For a healthy human diet, the values recommended for the PUFA/SFA, $n-6 / n-3$ and $n-3 / n-6$ ratios are a minimum value of 0.45 , a maximum value of 4.0 (Department of Health and Social Security, 1984) and a range from 1/1 to 1/5 (Zuraini et al., 2006), respectively. Based on the aformentioned limits, A. gigas can be considered a food matrix with a balanced fatty acid profile. Similar PUFA/SFA results were observed in Mastacembelus simack (Harlioglu \& Yilmaz, 2011), Labeo rohita and Cirrhinus mrigala (Memon et al., 2011) ranging from 1.35 to 1.40. In agreement with this, Volpe et al. (2015) found $n-6 / n-3$ and $n-3 / n-6$ ratios within the specified limits for Onchorynchus mykiss. Afkhami et al. (2011) studied different freshwater fish species (Cyprinus carpio and Ctenopharyngodon idella) and demonstrated values for the $n-3 / n-6$ ratio similar to the present results. Furthermore, the EPA+DHA value, another important index for cardiovascular health was calculated in A. gigas (Table 5). In agreement with the values found, other freshwater species also obtained low values for the aformentioned sum (Afkhami et al., 2011).

Table 5. Nutritional quality indices for the lipid fraction of Arapaima gigas fillets.

\begin{tabular}{|c|c|c|c|c|c|c|c|}
\hline Specie & PUFA/SFA & $n-6 / n-3$ & $n-3 / n-6$ & EPA+DHA & AI & TI & H/H \\
\hline A. gigas & $1.51 \pm 0.15$ & $3.59 \pm 0.46$ & $0.28 \pm 0.04$ & $8.82 \pm 0.63$ & $0.35 \pm 0.03$ & $0.28 \pm 0.01$ & $2.37 \pm 0.23$ \\
\hline
\end{tabular}

\subsection{Indices of lipid quality}

The fatty acid composition permits one to evaluate the nutritional quality of the lipid content by calculation of the atherogenicity index (AI), thrombogenicity index (TI) and hypocholesterolemic to hypercholesterolemic $(\mathrm{H} / \mathrm{H})$ ratio (Table 5). A high quality lipid fraction should have low AI and TI values but a high $\mathrm{H} / \mathrm{H}$ ratio (Bentes et al., 2009). In the present research, the $\mathrm{AI}$ and TI values were 0.35 and 0.28 , respectively. Nieminen et al. (2014) also reported AI and TI values below 1 in Acipenser baerii. According to Ulbricht \& Southgate (1991) low AI and TI values can inhibit the aggregation of platelets, preventing the appearance of coronary diseases, considered beneficial for human health. The $\mathrm{H} / \mathrm{H}$ ratio is related to the cholesterol metabolism where greater $\mathrm{H} / \mathrm{H}$ values are more desirable, representing a positive effect on 
human health (Fernandes et al., 2014). The A. gigas fillets exhibited an $\mathrm{H} / \mathrm{H}$ ratio of 2.37. A similar value for $\mathrm{H} / \mathrm{H}$ was demonstrated by Testi et al. (2006) for Oncorhynchus mykiss (2.43).

\section{Conclusions}

Arapaima gigas can be classified as a great protein source and a lean fish with high lipid quality, containing high long-chain PUFA levels and good nutritional indices within the freshwater fish group, emphasizing the importance of this specie on human health, mainly in the prevention of cardiovascular diseases. Nevertheless, the refrigerated and frozen storage temperatures were not capable of preventing lipid oxidation during the storage of A. gigas, probably due to large amount of PUFAs present in this specie. Further studies should focus on new conservation methods for this type of food matrix such as vacuum packaging, modified atmosphere packaging, oxygen scavenger packaging and antioxidant packaging.

\section{Acknowledgements}

The authors are grateful for the financial support provided by the Fundação Carlos Chagas Filho de Amparo à Pesquisa do Estado do Rio de Janeiro (FAPERJ), grant numbers E-26/010.001678/2016, E26/203.049/2017, E-26/202.305/2017 and E-26/202.306/2017; and the Conselho Nacional de Desenvolvimento Científico e Tecnológico (CNPq), grant number 311422/2016.

\section{References}

Abreu, D. P., Losada, P. P., Maroto, J., \& Cruz, J. M. (2011). Lipid damage during frozen storage of Atlantic halibut (Hippoglossus hippoglossus) in active packaging film containing antioxidants. Food Chemistry, 126(1), 315-320.

http://dx.doi.org/10.1016/j.foodchem.2010.10.048

Ackman, R. G. (1989). Nutritional composition of fats in seafoods. Progress in Food \& Nutrition Science, 13(3-4), 161-289. PMid:2699043.

Afkhami, M., Mokhlesi, A., Bastami, K. D., Khoshnood, R., Eshaghi, N., \& Ehsanpour, M. (2011). Survey of some chemical compositions and fatty acids in cultured common carp (Cyprinus carpio) and grass carp (Ctenopharyngodon idella), Noshahr, Iran. World Journal of Fish and Marine Sciences, 3(6), 533-538.

Arfat, Y. A., Benjakul, S., Vongkamjan, K., Sumpavapol, P., \& Yarnpakdee, S. (2015). Shelf-life extension of refrigerated sea bass slices wrapped with fish protein isolate/fish skin gelatin-ZnO nanocomposite film incorporated with basil leaf essential oil. Journal of Food Science and Technology, 52(10), 6182-6193. PMid:26396365. http://dx.doi.org/10.1007/s13197-014-1706-y

Association of Official Agricultural Chemists - AOAC. (2012). Official methods of analysis. 19th ed. Washington: AOAC.

Ateş, M., Çakiroğullari, G. Ç., Kocabaş, M., Kayim, M., Can, E., \& Kizak, V. (2013). Seasonal variations of proximate and total fatty acid composition of wild Brown Trout in Munzur River, Tunceli-Turkey. Turkish Journal of Fisheries and Aquatic Sciences, 13, 613619.

Bentes, A. S., Souza, H. A. L., Mendonça, X. M. F., \& Simões, M. G. (2009). Caracterização física e química e perfil lipídico de três espécies de peixes amazônicos. Revista Brasileira de Tecnologia Agroindustrial, 3(2), 97-108. http://dx.doi.org/10.3895/S198136862009000200011

Bligh, E. G., \& Dyer, W. J. (1959). A rapid method of total lipid extraction and purification. Canadian Journal of Biochemistry and Physiology, 37(8), 911-917. PMid:13671378. http://dx.doi.org/10.1139/o59-099

Buzzi, M., Henderson, R. J., \& Sargent, J. R. (1997). Biosynthesis of docosahexaenoic acid in trout hepatocytes proceeds via 24carbon intermediates. Comparative Biochemistry and Physiology. Part B, Biochemistry \& Molecular Biology, 116(2), $263-267$. PMid:9159889. http://dx.doi.org/10.1016/S0305-0491(96)00210-6

Canto, A. C., Costa-Lima, B. R., Suman, S. P., Monteiro, M. L. G., Marsico, E. T., Conte-Junior, C. A., Franco, R. M., Salim, A. P. A. A., Torrezan, R., \& Silva, T. J. P. (2015). Fatty acid profile and bacteriological quality of caiman meat subjected to high hydrostatic pressure. Lebensmittel-Wissenschaft + Technologie, 63(2), 872-877. http://dx.doi.org/10.1016/j.lwt.2015.05.003

Carani, F. R., Aguiar, D. H., Almeida, F. L. A., Gonçalves, H. S., Padovani, C. R., \& Silva, M. D. P. (2008). Morfologia e crescimento do músculo estriado esquelético no pirarucu Arapaima gigas Cuvier, 1817 (Teleostei, Arapaimidae). Acta Scientiarum. Biological Sciences, 30(2), 205-211.

Çelik, M., Diler, A., \& Küçükgülmez, A. (2005). A comparison of the proximate compositions and fatty acid profiles of zander (Sander lucioperca) from two different regions and climatic conditions. Food Chemistry, 92(4), 637-641. http://dx.doi.org/10.1016/j.foodchem.2004.08.026 
Chin, S. F., Liu, W., Storkson, J. M., Ha, Y. L., \& Pariza, M. W. (1992). Dietary sources of conjugated dienoic isomers of linoleic acid, a newly recognized class of anticarcinogens. Journal of Food Composition and Analysis, 5(3), 185-197. http://dx.doi.org/10.1016/0889-1575(92)90037-K

Conte-Junior, C. A., Soncin, S., Hierro, E., \& Fernandez, M. (2007). Estudio de la producción de ácido linoleico conjugado por cepas de lactobacillus y enterococcus de distintos orígenes. Revista Complutense de Ciencias Veterinarias, 1(2), 482-489. Department of Health and Social Security. (1984). Diet and cardiovascular disease. London: HMSO.

Fernandes, C. E., Vasconcelos, M. A. S., Ribeiro, M. A., Sarubbo, L. A., Andrade, S. A. C., \& Melo Filho, A. B. (2014). Nutritional and lipid profiles in marine fish species from Brazil. Food Chemistry, 160, 67-71. PMid:24799210. http://dx.doi.org/10.1016/j.foodchem.2014.03.055

Fogaça, F. H. S., Oliveira, E. G., Carvalho, S. E. Q., \& Santos, J. F. S. (2011). Yield and composition of pirarucu fillet in different weight classes. Acta Scientiarum. Animal Sciences, 33(1), 95-99. http://dx.doi.org/10.4025/actascianimsci.v33i1.10843

Gómez-Estaca, J., López-De-Dicastillo, C., Hernández-Muñoz, P., Catalá, R., \& Gavara, R. (2014). Advances in antioxidant active food packaging. Trends in Food Science \& Technology, 35(2), 42-51. http://dx.doi.org/10.1016/j.tifs.2013.10.008

Grigorakis, K., Alexis, M. N., Taylor, K. D., \& Hole, M. (2002). Comparison of wild and cultured gilthead sea bream (Sparus aurata); composition, appearance and seasonal variations. International Journal of Food Science \& Technology, 37(5), 477-484. http://dx.doi.org/10.1046/j.1365-2621.2002.00604.x

Guéraud, F., Atalay, M., Bresgen, N., Cipak, A., Eckl, P. M., Huc, L., Jouanin, I., Siems, W., \& Uchida, K. (2010). Chemistry and biochemistry of lipid peroxidation products. Free Radical Research, 44(10), 1098-1124. PMid:20836659. http://dx.doi.org/10.3109/10715762.2010.498477

Guyon, C., Meynier, A., \& Lamballerie, M. (2016). Protein and lipid oxidation in meat: a review with emphasis on high-pressure treatments. Trends in Food Science \& Technology, 50, 131-143. http://dx.doi.org/10.1016/j.tifs.2016.01.026

Haard, N. F. (1992). Control of chemical composition and food quality attributes of cultured fish. Food Research International, 25(4), 289-307. http://dx.doi.org/10.1016/0963-9969(92)90126-P

Harlioglu, A. G., \& Yilmaz, Ö. (2011). Fatty acid composition, cholesterol and fat-soluble vitamins of wild-caught freshwater spiny eel, Mastacembelus simack (Walbaum, 1792). Journal of Applied Ichthyology, 27(4), 1123-1127.

Henderson, R. J., Sargent, J. R., \& Hopkins, C. E. (1984). Changes in the content and fatty acid composition of lipid in an isolated population of the capelin, Mallotus villosus, during sexual maturation and spawning. Marine Biology, 78(3), 255-263. http://dx.doi.org/10.1007/BF00393011

Hunter, B. J., \& Roberts, D. C. (2000). Potential impact of the fat composition of farmed fish on human health. Nutrition Research, 20(7), 1047-1058. http://dx.doi.org/10.1016/S0271-5317(00)00181-0

Huynh, M. D., \& Kitts, D. D. (2009). Evaluating nutritional quality of pacific fish species from fatty acid signatures. Food Chemistry, 114(3), 912-918. http://dx.doi.org/10.1016/j.foodchem.2008.10.038

Imbiriba, E. P. (2001). Potencial de criação de pirarucu, Arapima gigas, em cativeiro. Acta Amazonica, 31(2), 299-316. http://dx.doi.org/10.1590/1809-43922001312316

Intarasirisawat, R., Benjakul, S., Visessanguan, W., \& Wu, J. (2014). Effects of skipjack roe protein hydrolysate on properties and oxidative stability of fish emulsion sausage. Lebensmittel-Wissenschaft + Technologie, 58(1), 280-286. http://dx.doi.org/10.1016/j.Iwt.2014.02.036

Jabeen, F., \& Chaudhry, A. S. (2011). Chemical compositions and fatty acid profiles of three freshwater fish species. Food Chemistry, 125(3), 991-996. http://dx.doi.org/10.1016/j.foodchem.2010.09.103

Jankowska, B., Zakęś, Z., Żmijewski, T., \& Szczepkowski, M. (2003). A comparison of selected quality features of the tissue and slaughter yield of wild and cultivate pikeperch Sander lucioperca (L.). European Food Research and Technology, 217(5), 401-405. http://dx.doi.org/10.1007/s00217-003-0757-5

Kishino, S., Ogawa, J., Ando, A., Omura, Y., \& Shimizu, S. (2002). Ricinoleic acid and castor oil as substrates for conjugated linoleic acid production by washed cells of lactobacillus plantarum. Bioscience, Biotechnology, and Biochemistry, 66(10), 22832286. PMid:12450151. http://dx.doi.org/10.1271/bbb.66.2283

Kumar, Y., Yadav, D. N., Ahmad, T., \& Narsaiah, K. (2015). Recent trends in the use of natural antioxidants for meat and meat products. Comprehensive Reviews in Food Science and Food Safety, 14(6), 796-812. http://dx.doi.org/10.1111/15414337.12156

López-De-Dicastillo, C., Gómez-Estaca, J., Catalá, R., Gavara, R., \& Hernández-Muñoz, P. (2012). Active antioxidant packaging films: Development and effect on lipid stability of brined sardines. Food Chemistry, 131(4), 1376-1384. http://dx.doi.org/10.1016/j.foodchem.2011.10.002

Martínez-González, M. A., Fernández-Jarne, E., Serrano-Martínez, M., Marti, A., Martinez, J. Á., \& Martín-Moreno, J. M. (2002). Mediterranean diet and reduction in the risk of a first acute myocardial infarction: an operational healthy dietary score. European Journal of Nutrition, 41(4), 153-160. PMid:12242583. http://dx.doi.org/10.1007/s00394-002-0370-6

Martins, M. G., Martins, D. E. G., \& Pena, R. S. (2015). Drying kinetics and hygroscopic behavior of pirarucu (Arapaima gigas) fillet with different salt contents. Lebensmittel-Wissenschaft + Technologie, 62(1), 144-151.

http://dx.doi.org/10.1016/j.Iwt.2015.01.010 
Memon, N. N., Talpur, F. N., Bhanger, M. I., \& Balouch, A. (2011). Changes in fatty acid composition in muscle of three farmed carp fish species (Labeo rohita, Cirrhinus mrigala, Catla catla) raised under the same conditions. Food Chemistry, 126(2), 405-410. http://dx.doi.org/10.1016/j.foodchem.2010.10.107

Merrill, A. L., \& Watt, B. K. Energy value of foods: basis and derivation. Washington: ARS USDA, 1973. 109 p.

Monteiro, M. L. G., Mársico, E. T., Teixeira, C. E., Mano, S. B., Conte Júnior, C. A., \& Vital, H. C. (2012). Validade comercial de filés de Tilápia do Nilo (Oreochromis niloticus) resfriados embalados em atmosfera modificada e irradiados. Ciência Rural, 42(4), 737743. http://dx.doi.org/10.1590/S0103-84782012000400027

Navarro, R. D., Navarro, F. K. S. P., Ribeiro Filho, O. P., Ferreira, W. M., Pereira, M. M., \& Seixas Filho, J. T. (2012). Quality of polyunsaturated fatty acids in Nile tilapias (Oreochromis niloticus) fed with vitamin E supplementation. Food Chemistry, 134(1), 215218. http://dx.doi.org/10.1016/j.foodchem.2012.02.097

Nieminen, P., Westenius, E., Halonen, T., \& Mustonen, A. (2014). Fatty acid composition in tissues of the farmed Siberian sturgeon (Acipenser baerii). Food Chemistry, 159, 80-84. PMid:24767029. http://dx.doi.org/10.1016/j.foodchem.2014.02.148

Oliveira, P. R., Jesus, R. S., Batista, G. M., \& Lessi, E. (2014). Avaliação sensorial, físico-química e microbiológica do pirarucu (Arapaima gigas, Schinz 1822) durante estocagem em gelo. Brazilian Journal of Food Technology, 17(1), 67-74. http://dx.doi.org/10.1590/bjft.2014.010

Sanders, T. A. B. (2016). Functional dietary lipids: food formulation, consumer issues and innovation for health (332 pp.). Cambridge: Woodhead Publishing.

Santos, J. S. L., Mársico, E. T., Lemos, M., Cinquini, M. A., Silva, F. A., Dutra, Y. B., Franco, R. M., Conte-Junior, C. A., \& Monteiro, M. L. G. (2018). Effect of the UV-C radiation on shelf life of vacuum-packed refrigerated pirarucu (Arapaima gigas) fillets. Journal of Aquatic Food Product Technology, 27(1), 48-60. http://dx.doi.org/10.1080/10498850.2017.1402840

Santos-Silva, J., Bessa, R. J. B., \& Santos-Silva, F. (2002). Effect of genotype, feeding system and slaughter weight on the quality of light lambs: II. Fatty acid composition of meat. Livestock Production Science, 77(2-3), 187-194.

http://dx.doi.org/10.1016/S0301-6226(02)00059-3

Shichiri, M., Adkins, Y., Ishida, N., Umeno, A., Shigeri, Y., Yoshida, Y., Fedor, D. M., Mackey, B. E., \& Kelley, D. S. (2014). DHA concentration of red blood cells is inversely associated with markers of lipid peroxidation in men taking DHA supplement. Journal of Clinical Biochemistry and Nutrition, 55(3), 196-202. PMid:25411526. http://dx.doi.org/10.3164/jcbn.14-22

Simopoulos, A. P. (2009). Evolutionary aspects of the dietary omega-6:omega-3 fatty acid ratio: medical implications. World Review of Nutrition and Dietetics, 100, 1-21. PMid:19696523. http://dx.doi.org/10.1159/000235706

Tarladgis, B. G., Watts, B. M., Younathan, M. T., \& Dugan Junior, J. L. (1960). A distillation method for the quantitative determination of malonaldehyde in rancid foods. Journal of the American Oil Chemists' Society, 37(1), 44-48. http://dx.doi.org/10.1007/BF02630824

Testi, S., Bonaldo, A., Gatta, P. P., \& Badiani, A. (2006). Nutritional traits of dorsal and ventral fillets from three farmed fish species. Food Chemistry, 98(1), 104-111. http://dx.doi.org/10.1016/j.foodchem.2005.05.053

Thammapat, P., Raviyan, P., \& Siriamornpun, S. (2010). Proximate and fatty acids composition of the muscles and viscera of Asian catfish (Pangasius bocourti). Food Chemistry, 122(1), 223-227. http://dx.doi.org/10.1016/j.foodchem.2010.02.065

Ulbricht, T. L. V., \& Southgate, D. A. T. (1991). Coronary heart disease: seven dietary factors. Lancet, 338(8773), 985-992. PMid:1681350. http://dx.doi.org/10.1016/0140-6736(91)91846-M

Volpe, M. G., Siano, F., Paolucci, M., Sacco, A., Sorrentino, A., Malinconico, M., \& Varricchio, E. (2015). Active edible coating effectiveness in shelf-life enhancement of trout (Oncorhynchus mykiss) fillets. Lebensmittel-Wissenschaft + Technologie, 60(1), 615-622. http://dx.doi.org/10.1016/j.Iwt.2014.08.048

Zaki, M. E., El-Bassyouni, H., Kamal, S., El-Gammal, M., \& Youness, E. (2014). Association of serum paraoxonase enzyme activity and oxidative stress markers with dyslipidemia in obese adolescents. Indian Journal of Endocrinology and Metabolism, 18(3), 340344. PMid:24944928. http://dx.doi.org/10.4103/2230-8210.131173

Zuraini, A., Somchit, M. N., Solihah, M. H., Goh, Y. M., Arifah, A. K., Zakaria, M. S., Somchit, N., Rajion, M. A., Zakaria, Z. A., \& Mat Jais, A. M. (2006). Fatty acid and amino acid composition of three local Malaysian Channa spp. fish. Food Chemistry, 97(4), 674678. http://dx.doi.org/10.1016/j.foodchem.2005.04.031

Funding: Fundação Carlos Chagas Filho de Amparo à Pesquisa do Estado do Rio de Janeiro (FAPERJ), grant numbers E-

26/010.001678/2016, E-26/203.049/2017, E-26/202.305/2017 and E-26/202.306/2017; and Conselho Nacional de Desenvolvimento Científico e Tecnológico (CNPq) grant number 311422/2016, 427747/2018-0, and 406777/2018-7. 